\title{
A Profit Target-Oriented Pricing Model of Internet Finance Product in Commercial Bank
}

\author{
Manduo Liu', a \\ ${ }^{1}$ School of Business, Zhengzhou University, Zhengzhou 450001, China; \\ amanduoliu@163.com
}

Keywords: Internet finance, pricing model, commercial bank.

\begin{abstract}
With the advancement of Internet technology, the operating and competitive environment of China's banking industry has undergone radical changes. Some of the traditional banking businesses and functions are increasingly weakened, and the bank's business forms and profit models are facing unprecedented challenges. Based on Internet technology, vigorously expanding online financial services is the key strategic way out for financial sector. From the perspectives of the basic concepts and main characteristics of Internet finance, this study designs the pricing model of Internet financial products in commercial bank based on the factors such as customer comprehensive contribution and bank profit target. This study can provide scientific guidance for the pricing of commercial banks' Internet financial products.
\end{abstract}

\section{Introduction}

The progress of Internet and modern information technology, especially the continuous development of big data, cloud computing, mobile Internet, search engine and social platform network, subverts many traditional areas of the industry. And the way of life of the inhabitants is also undergoing profound changes, the financial industry is no exception. In recent years, the financial sector is most affected by the Internet after the commercial supply and marketing, news media, logistics, etc. Many financial products and services model based on the Internet came into being, and "Internet finance" has gradually become the focus of attention of the community. Internet finance is a new financial services model which uses the Internet as a resource platform, and based on big data, cloud computing. Cloud computing is its core technology; big data is its core resources. Internet finance is a resource platform rather than a technology platform, which will effectively carry out the Internet as a financial activity. It relies on cloud computing and other big data processing technology, and captures the historical data information in the network through the search engine and other ports. After high-quality screening, processing large amounts of information contained in the massive information resources, financial credit system gradually formed based on the Internet information platform. Data-driven financial services model reduces information asymmetry and improves risk pricing capacity [1-3].

Internet finance and traditional finance have different characteristics: (1) Grassroots finance. "Grassroots finance" is ignored by traditional financial institutions. Various institutions attach importance to VIP customers, and continuously improve the quality of service to VIP customers. Internet finance has broken the high threshold of traditional financial industry, with flexible, efficient and convenient as the main features. It seeks a breakthrough in financial demand for small and medium-sized customers and small groups, expanding the breadth and depth of financial services. (2) Internet technology greatly reduces the client's distance in time and space to establish a new financial services format. Internet platform took the place of the traditional financial institutions of the intermediary role, implementing the service which is a large collection of cash flow, information flow, and logistics to become a port where customers can enjoy the service conveniently. (3) People in the field of the Internet left social, business, life and other aspects of debris data, which contains massive structured and unstructured information, including the transaction behavior, trading ways, trading 
history, payment, defaults etc. The integration of these information fragments is an important resource and asset. For the customers differ in the size of assets, financing needs, credit levels and other aspects, Internet finance can effectively use idle funds and integrate small customers and small micro-groups, resulting in a strong polymerization force and achieve scale effects, which will become the innovation power and new profit growth point of banks, securities and other traditional financial institutions [4].

Finance mainly relies on product innovation and product pricing to get their own ability to survive. Internet financial customer experience has been deepened, the cost has been reduced. Nevertheless, if the core problem of pricing method cannot be solved, the customer stock and customer flow will be useless. At present, the main operators in China of the Internet finance are Internet companies and e-commerce platforms. Such non-bank institutions are inherently deficient in the pricing and risk management and other aspects, which restricts its further development [5]. However, traditional commercial banks have a unique risk management system and a mature corporate governance structure. Therefore, drawing on the research results of deposit and loan, intermediary business and other product pricing aspects from benchmarking banks in developed countries, and based on the comprehensive contribution of the customer, bank profit targets and other elements, this study designs the pricing model of bank Internet financial products, which can provide scientific guidance for the pricing of commercial bank Internet financial products.

\section{Design of Profit-oriented Pricing Model of Bank Internet Financial Business}

With the continuous progress of interest rate marketization process in China, Internet financial products have achieved market-oriented pricing ahead of the traditional banking products, which is closer to the current interbank placement between commercial banks. In order to further adapt to the current financial development trends and consolidate customer relations. It is necessary to design and improve the pricing model of the bank Internet financial products for the development of commercial banking business at the right cost and price. The Internet finance in China is at stake, but the pricing principle is not clear. Therefore, it is necessary to draw on the western commercial banks in the deposit, loan, intermediary business and other aspects of product pricing research to design and improve the bank's Internet financial product pricing model according to the specific circumstances of commercial banks in China.

The contributions to the bank brought by the funds of customers who use to buy the Internet financial products are mainly assets, liabilities, intermediary business three aspects, there are:

$$
C_{a}+C_{d}+C_{m}=C
$$

Where $C$ represents the sum of the contribution of the customer who purchased the bank's financial products to the bank. $\mathrm{C}_{a}$ represents the customer's contribution to the asset business. $\mathrm{C}_{d}$ represents the customer's contribution to the liability business. $\mathrm{C}_{m}$ represents the customer's contribution to the intermediary business.

\subsection{A Model Design to Measure the Contribution of Asset Business.}

The difference from the corporate regarding the traditional credit business as the main asset business is that assets business of the Internet financial takes convenience and flexibility as the main features. Following the current non-bank Internet financing company's business model, the bank's Internet financing can apply advanced Internet technology to financing services. Using Internet technology to improve pre-loan investigation and audit, loan process, post-loan supervision and loan repayment and other steps becomes an another valve of commercial bank income.

Let $C_{a 1}, C_{a 2}, C_{a 3}, \ldots$ be the contribution level of each asset business respectively, there are:

$$
\begin{aligned}
& \sum_{i=1}^{\mathrm{n}} C_{a}=C_{a 1}+C_{a 2}+\ldots \ldots . .+C_{a n} \\
& C_{a 1}=I_{i}-\left(\mathrm{T}_{i}+\mathrm{E}_{f t p}+\mathrm{L}_{o i}+\mathrm{F}_{r i}\right)
\end{aligned}
$$


Where $I_{i}$ represents the simulated interest income that the $i$ th asset business can achieve, $T_{i}$ represents the tax expenditure in the $i$ th asset business, $E_{f t p}$ represents the capital cost to raise funds approved by the $i$ th asset business within the bank (internal capital transfer pricing). $L_{o i}$ represents the possible loss of risk for the $i$ th asset business, and $F_{r i}$ represents the operating expenses and HR costs of the $i$ th business. Here, the cost of capital (internal capital transfer pricing) can be refined further:

$\mathrm{E}_{f t p}=A_{i} \times r_{f t p} \times t_{\mathrm{i}}$

Where $A_{i}$ represents the amount of financing for the $i$ th asset business, $r_{f t p}$ represents the internal capital transfer price for the $i$ th asset business, and $t_{i}$ represents the duration of the $i$ th asset business. At the same time, we refine $I_{i}$ further:

$I_{i}=A_{i} \times R_{i} \times t_{i}$

Where $R_{i}$ represents the financing rate of the $i$ th asset business.

Let's bring the formula (4), (5) into (3), we can get:

$C_{a 1}=A_{i} \times R_{i} \times t_{i}-\left(T_{i}+A_{i} \times r_{f t p} \times t_{i}+L_{o i}+F_{r i}\right)$

Let's bring the formula (6) into the formula (2), you can get $\mathrm{C}_{a}$ :

$\mathrm{C}_{a}=\sum_{i=1}^{n}\left[\mathrm{~A}_{i} \times \mathrm{R}_{i} \times \mathrm{t}_{i}-\left(\mathrm{T}_{i}+\mathrm{A}_{i} \times r_{f t p} \times t_{i}+\mathrm{L}_{o i}+\mathrm{F}_{r i}\right)\right]$

Then $\mathrm{C}_{a}$ of the formula (7) is the contribution degree of the Internet financial asset business.

\subsection{A Model Designed to Measure the Contribution Degree of debt business.}

Internet financial liability business products are the important source of funding of commercial bank loans, investment and other business. In addition, the " The balance of treasure " and other Internet products do not need to pay the deposit reserve to the People's Bank, which is different from the funds banks' Internet financial accepts need to pay the deposit reserve. Therefore, the contribution still needs to consider the interest income of the deposit reserve. So we define $C_{d 1}, C_{\mathrm{d} 2}, C_{\mathrm{d} 3}, \ldots$ as the contribution degree of each debt business respectively. There is:

$\sum_{i=1}^{n} C_{d}=C_{d 1}+C_{d 2}+\ldots .+C_{d n}$

In the formula (8), the formula for calculating the contribution of the liability business is:

$C_{d i}=D_{i} \times(1-\mathrm{s}) \times r_{f t p 0} \times t+D_{i} \times \mathrm{s} \times r_{s} \times t+D_{i} \times R_{r} \times D_{r r} \times t-\left(\mathrm{ie}+\mathrm{F}_{r i}\right)$

In the formula (9), $D_{i}$ represents the daily average balance of the $i$ th deposit, $s$ represents the reserve ratio, $r_{f i p 0}$ represents the bank's approved capital cost and the internal capital transfer pricing, $t$ represents the deposit term, $r_{s}$ represents the single-day interest rate of the excess reserves, $R_{r}$ represents the statutory deposit reserve ratio announced by the central bank, $D_{r r}$ represents the single-day interest rate of the deposit reserve, ie represents the interest expense, $F_{r i}$ means the operating expenses and the employee's salary costs. Among them there is:

$$
\text { ie }=D_{i} \times r_{i} \times t
$$

In the formula (10), $r_{i}$ represents the interest rate of the proposed Internet financial liability business.

Substituting the formula (10) into the formula (9), there is:

$C_{d i}=D_{i} \times(1-s) \times r_{f t p 0} \times t+D_{i} \times s \times r_{s} \times t+D_{i} \times R_{r} \times D_{r r} \times t-\left(D_{i} \times r_{i} \times t+F_{r i}\right)$

Substituting the formula (11) into the formula (8), there is:

$C_{d}=\sum_{i=1}\left[D_{i} \times(1-s) \times r_{f t p 0} \times t+D_{i} \times s \times r_{s} \times t+D_{i} \times R_{r} \times D_{r r} \times t-\left(D_{i} \times r_{i} \times t+F_{r i}\right)\right]$ 


\subsection{A Model Designed to Measure the Contribution Degree of Intermediate Business.}

Bank's Internet financial intermediary business incomes are mainly from the third-party payment, agency settlement, network securities, and financial trust plan and so on. Let $C_{m 1}, C_{m 2}, C_{m 3} \cdots$ represent the contribution of each intermediate business respectively. There is:

$C_{m}=C_{m 1}+C_{m 2}+C_{m 3}+\ldots \ldots . .+C_{m n}=\sum_{i=1}^{n} C_{m i}$

Among the formula above, there is $C_{m i}=I_{m i}-F_{m r i} . I_{m i}$ represents the revenue achieved by the $i$ th intermediate business, $F_{m r i}$ represents the operating costs of the $i$ th intermediate business and the employee's salary costs. There is:

$$
C_{m}=C_{m 1}+C_{m 2}+C_{m 3}+\ldots \ldots . .+C_{m n}=\sum_{i=1}^{n}\left(I_{m i}-F_{m r i}\right)
$$

Finally, bring the formula (7), (12), (14) into the formula (1), and we can get the comprehensive contribution formula of Internet financial customers:

$$
\begin{aligned}
& C=C_{a}+C_{d}+C_{m} \\
& =\sum_{i=1}^{n}\left[\mathrm{~A}_{i} \times \mathrm{R}_{i} \times \mathrm{t}_{i}-\left(\mathrm{T}_{i}+\mathrm{A}_{i} \times r_{f t p} \times t_{i}+\mathrm{L}_{o i}+\mathrm{F}_{r i}\right)\right] \\
& +\sum_{i=1}^{n}\left[D_{i} \times(1-s) \times r_{f t p 0} \times t+D_{i} \times s \times r_{s} \times t+D_{i} \times R_{r} \times D_{r r} \times t-\left(D_{i} \times r_{i} \times t+F_{r i}\right)\right]+\sum_{i=1}^{n}\left(I_{m i}-F_{m r i}\right)
\end{aligned}
$$

According to the principle of model designing, the comprehensive contribution of bank's Internet financial customers should be equal to the bank's target profit of Internet financial clients. So the bank's target profit $P$ is brought into the formula above, there is:

$$
\begin{aligned}
& C=C_{a}+C_{d}+C_{m} \\
& =\sum_{i=1}^{n}\left[\mathrm{~A}_{i} \times \mathrm{R}_{i} \times \mathrm{t}_{i}-\left(\mathrm{T}_{i}+\mathrm{A}_{i} \times r_{f t p} \times t_{i}+\mathrm{L}_{o i}+\mathrm{F}_{r i}\right)\right] \\
& +\sum_{i=1}^{n}\left[D_{i} \times(1-s) \times r_{f t p 0} \times t+D_{i} \times s \times r_{s} \times t+D_{i} \times R_{r} \times D_{r r} \times t-\left(D_{i} \times r_{i} \times t+F_{r i}\right)\right]+\sum_{i=1}^{n}\left(I_{m i}-F_{m r i}\right)=P
\end{aligned}
$$

From the formula above, interest rate $r_{i}$ of the Internet financial liability business products which are needed prized can be derived. When $P=0$, that is, when the bank's target profit is zero, the calculated interest rate level $r_{i}$ of the bank's Internet financial liability business is the highest interest rate that the bank can give, and the real interest rate level should not exceed the interest rate cap in principle.

\section{Conclusions}

Based on the factors of the comprehensive contribution of customers and the profit target of banks, this paper designs the pricing model of bank Internet financial products. The product pricing form regarding the comprehensive contribution that customers bring as the subjects is in line with the Internet financial generally-favorable thought, and "customer-centric" business philosophy, and adapt to the inevitable trend of online financial competition. In terms of customers, the contribution of Internet financial products includes assets, liabilities and intermediate business and other aspects, the risks of which are more dispersed. Especially, because deposit and loan interest rates of the Internet financial have been achieved market-oriented pricing, that is, according to the supply and demand of funds, the prices of funds can be determined. Commercial banks are faced with the price games with other banks or e-commerce platforms. Therefore, combining with the actual situation of 
commercial banks, and designing a set of realizable product pricing models, which is necessary to adapt to the future development and competition.

The pricing model designed in this paper focuses on the quantitative factors, but the qualitative and quantitative factors should be considered together in the practical work. Such as the customers' market influence, strategic cooperation possibility, and development potential and so on. In the specific research, we can use expert scoring method which fully reflects the comprehensive value of customers from an objective view. At the same time, in the pricing process, we should also be based on the factors of bank's development strategy, market competition situation to adjust the target profit flexibly, finally affecting the price of funds. We can refer to the various rates of financial, P2P loans, small-micro credit loans and others, considering the price of our own bank's Internet financial products dynamically.

\section{References}

[1] Ping, X., \& Chuanwei, Z. the theory of Internet finance. (2013).

[2] Hailong, H. Research of the Internet Finance with the Core as E-commerce Platform [J]. Shanghai Finance, 8, 002.

[3] Jie, S., \& Chen, H. (2015). Internet Finance Innovation and Traditional Bank Transformation Based on Big Data.". Finance \& Economics, 1(002).

[4] Cao, S., Chang, L., Yu, Y., \& Yang, X. A Review of Current Studies on Internet Finance in China. In WHICEB (2014, June). p. 42.

[5] Banks, E. e-Finance: the electronic revolution in financial services. John Wiley \& Sons, Inc.(2001). 